\title{
Changes in Morphological and Biochemical Parameters of Blood of Broiler Chickens Caused by Use of Feed Additives
}

\author{
Mukhamediarova Zulfiya Petrovna \\ Instructor at the Federal State Budgetary \\ Educational Institution of Higher Education \\ "South Ural State Agrarian University" \\ Troitsk Agrarian Technical School \\ Troitsk, Russia \\ e-mail: zulfiya-makarova@mail.ru
}

\author{
Mizhevikina Anna Sergeevna \\ Associate Professor of the Department of Veterinary \\ and Sanitary Inspection and Commodity Science of \\ Consumer Goods \\ Federal State Budgetary \\ Educational Institution of Higher Education \\ "South Ural State Agrarian University" \\ Troitsk Agrarian Technical School \\ Troitsk, Russia
}

\author{
Lykasova Irina Aleksandrovna \\ Professor of the Department of Veterinary and Sanitary \\ Inspection and Commodity Science of Consumer Goods \\ Federal State Budgetary \\ Educational Institution of Higher Education \\ "South Ural State Agrarian University" \\ Troitsk Agrarian Technical School \\ e-mail: irina41056@mail.ru
}

\begin{abstract}
NaBiKat and Sinbilite are feed additives that stimulate erythropoiesis and saturation of erythrocytes with hemoglobin, as well as activate the metabolism of proteins, minerals, and carbohydrates. The combined use of additives did not reveal any pronounced increase in the effect of stimulating productivity. The markers of positive effects of the additives on productivity can be assumed to be the decrease of urea in blood serum and the increase of total protein, creatinine, and glucose.
\end{abstract}

Keywords- NaBiKat; Sinbilite; morphological and biochemical blood values

\section{INTRODUCTION}

Blood is one of the basic of the milieu interieur and is characterized by a relatively constant composition and physical and chemical properties, which ensures the necessary conditions for the vital activity of an organism's cells and tissues. The general physiological parameters of bird blood are subject to changes depending on feeding and housing conditions [1]. Use of poultry feeds and feed additives can positively affect the growth, development, and livability of young chickens [2].

Synbiotics are used to form immunity in poultry, optimize its digestion, and stimulate its growth and development. The current recommendation for poultry farming is Sinbilite, a feed additive with probiotic and prebiotic effects [3]. Probiotics do not affect the microflora of the digestive tract adversely, do not pollute animal products and the environment, and are environmentally friendly. Using them is safe for people who consume animal products [4].

Besides synbiotics, farmers use mineral feeds in optimal amounts and ratios and in strict compliance with the needs of the poultry [5]. At the moment, mixtures based on chelated silica and gallocatechin are used as efficient poultry feed additives. One such additive is $\mathrm{NaBiKat}$, a complex compound with biocatalyst properties [6]

Influence of additives containing water-soluble silica on bird organisms was researched by: A.S. Mizhevikina, I.A. Lykasova, D.V. Poluboiarov, V.B. Odeianko (2017) Furthermore, A.S. Mizhevikina and I.A. Lykasova (2017) carried out an experimental study of the influence of NaBiKat and Sinbilite on the formation and development of chicks' mucus layer $[7,8]$.

However, studies of the influence of feed additives on hematological and biochemical parameters are scarce and this issue needs to be further researched.

In this regard, a goal was set to carry out a comparative study of the influence of $\mathrm{NaBiKat}$ and Sinbilite on the blood values of broiler chickens, as well as to evaluate the option of their combined use, and to identify the biochemical indicators: the markers of further improvements of meat poultry productivity. 


\section{MATERIALS AND METHODS}

The experiment for studying the effect of $\mathrm{NaBiKat}$ and Sinbilite on the morphological and biochemical parameters of broiler chickens was carried out from January to March 2017, based in Bektysh poultry farm by OOO Bektysh in Yetkulsky District, Chelyabinsk Oblast, Russia. The experiment involved 4000 broiler chicks of the KOBB 500 cross. The chickens were contained in four-tier battery cages. According to the law of similarity, they were split into four groups: the control group and three treatment groups, whose rations included feed supplements in the following doses:

- birds from treatment group 2 were fed $\mathrm{NaBiKat}$ at the dose of $2 \mathrm{~kg}$ per 1 ton of fodder;

- birds from treatment group 3 were fed Sinbilite at the dose of $350 \mathrm{~g}$ per 1 ton of fodder;

- rations of the birds from treatment group 4 included both NaBiKat and Sinbilite at the doses indicated above.

The control group (group 1) did not receive any additives and was given the farm's regular rations.

The experiment lasted 38 days.
Blood tests were performed in the laboratory of poultry farming and the laboratory of the Innovative Research Center of the FSBEIHE "South Ural State Agrarian University".

Red and white blood cells, hemoglobin content, total protein, protein fractions, urea, calcium, inorganic phosphorus, and magnesium in the blood serum were identified using the current techniques recognized in veterinary medicine [9], glucose was identified through the fermentation method using the "Glyukoza FKD" kit, creatinine was detected with the "Bio-La-Test" kit, and ALT and AST were measured using the Reitman-Frankel unified method [10-13]. The content of iron, zinc, manganese, copper, cobalt, nickel, lead, and cadmium in muscle tissue was determined using atomic absorption spectroscopy according to GOST 30178-96 standards [14]. The statistical processing of the outcomes was carried out in Microsoft Office Excel 2007 using the "biometrics" routine.

\section{RESEARCH OUTCOMES}

Feeding intensity, nutritional breakdown, and use of feed additives and premixes have the most pronounced effect on the morphological composition of blood [15].

In the process of study, it was identified that the additives had a positive effect on the morphological composition of blood. The results are presented in Table 1 .

TABLE I.

CONTENT OF RED AND WHITE BLOOD CELLS AND HEMOGLOBIN IN THE BLOOD OF BROILER TEST SUBJECTS, $(\mathrm{X}+\mathrm{SX}, \mathrm{N}=5$ )

\begin{tabular}{|c|c|c|c|}
\hline Group & Red blood cells, $10^{12} \mid$ & Hemoglobin, g/l & White blood cells, $10^{9} / 1$ \\
\hline 1 st control & $2.52 \pm 0.24$ & $96.70 \pm 3.70$ & $32.60 \pm 3.60$ \\
\hline 2nd treatment & $2.68 \pm 0.22$ & $109.30 \pm 5.20^{*}$ & $32.80 \pm 4.40$ \\
\hline 3rd treatment & $2.67 \pm 0.13$ & $99.60 \pm 4.30$ & $33.50 \pm 3.50$ \\
\hline 4th treatment & $2.54 \pm 0.18$ & $107.30 \pm 5.10^{*}$ & $32.90 \pm 2.70$ \\
\hline
\end{tabular}

The data in Table 1 show that the changes in the blood of the chicks from treatment groups indicated a trend towards increased hemoglobin compared with the control group data. This is explained by that then value of red blood cells increased in all groups, albeit non-credibly. The largest increase in this value occurred in the groups whose rations were supplemented with $\mathrm{NaBiKat}$ (the 2 nd and the 4th). This way, the red blood cell content in the 2 nd group was higher than in the $3 \mathrm{rd}$ and 4 th by $0.3 \%$ and $5.5 \%$ respectively. In the second group, where only NaBiKat was used, the increase in red blood cells and hemoglobin was more pronounced. Unidirectional change in the number of white blood cells was not observed in all treatment groups, their variation was within the physiological norm.

The results of the changes in the biochemical parameters of the broiler chickens' blood are shown in Table 2.

TABLE II. EFFECT OF THE FEED MIXES ON THE BIOCHEMICAL PARAMETERS OF BROILER CHICKEN BLOOD, $(\mathrm{X}+\mathrm{SX}, \mathrm{N}=5)$

\begin{tabular}{|c|c|c|c|c|}
\hline \multirow{2}{*}{ Parameter: } & \multicolumn{5}{|c|}{ Group } \\
\cline { 2 - 5 } & 1st control & 2nd treatment & 3rd treatment & 4th treatment \\
\hline Total protein, g/1 & $36.42 \pm 0.81$ & $42.59 \pm 1.20^{*}$ & $41.12 \pm 0.95^{*}$ & $38.23 \pm 1.04$ \\
\hline Albumins, g/1 & $41.10 \pm 1.47$ & $39.76 \pm 0.24$ & $40.19 \pm 2.58$ & $34.96 \pm 0.38^{* *}$ \\
\hline$\alpha$-globulins, g/1 & $18.62 \pm 0.69$ & $17.95 \pm 1.16$ & $19.82 \pm 1.44$ & $16.07 \pm 1.26^{*}$ \\
\hline$\beta$-globulins, g/1 & $8.31 \pm 1.20$ & $8.31 \pm 0.31$ & $12.11 \pm 1.66^{*}$ & $12.79 \pm 2.12^{*}$ \\
\hline$\gamma$-globulins, g/1 & $31.97 \pm 1.13$ & $33.97 \pm 1.16$ & $33.88 \pm 1.20$ & $36.18 \pm 1.15^{*}$ \\
\hline Urea, mmol/1 & $1.17 \pm 0.10$ & $1.05 \pm 0.03$ & $1.20 \pm 0.03$ & $1.06 \pm 0.03$ \\
\hline Glucose, $\mathrm{mmol} / 1$ & $12.43 \pm 0.70$ & $12.03 \pm 0.82$ & $13.80 \pm 0.97$ & $12.73 \pm 1.16$ \\
\hline Creatinine, $\mathrm{mmol} / 1$ & $20.23 \pm 2.93$ & $44.27 \pm 8.87$ & $53.13 \pm 5.11$ & $47.23 \pm 2.93$ \\
\hline
\end{tabular}


According to the data from Table 2, the total protein content in the control group was below the norm, while in all treatment groups it was significantly above the control: in the 2nd and 3rd groups the credible values were $16.94 \%$ and $12.9 \%$ higher respectively and in the 4th it was $4.97 \%$. Albumin content in the blood serum of all treatment groups of chickens was below the control: by $2.2-14.9 \%$ on average. Globulin values in the treatment groups were different, but only the values of the 3rd and 4th treatment groups had a credible difference with the control. This way, the 3 rd and the 4th groups observed the $45.7 \%$ and $53.9 \%$ increase in $\beta$ globulin as compared with the control group. The priority of all feed additives was to increase the level of total protein in the blood serum because stimulating growth and development requires additional protein consumption, while the consumption of albumins as transport proteins frequently increases. The compound for the 2 nd treatment group (NaBiKat) showed a more pronounced and credible effect on the blood protein assay. The total content of protein in the group whose feed included this additive was higher than in the 3rd and 4th groups by 3.5. and 11.4 respectively.

The level of urea in the blood is the reflection of the speed of protein synthesis in the liver and the speed of renal elimination with urine. If the synthesis is impeded, proteins are consecutively accumulated in the blood. The level of urea in the blood serum of the 2 nd and 4 th groups did not have any statistically credible difference with the control group. The group that was fed Sinbilite displayed the level of urea above the control by $2.56 \%$ but almost two times below the regulatory boundary. The decrease of urea in the blood of the treatment group chicks was accompanied by the increase of the concentration of the total protein. This data signalize the high level of protein synthesis in the birds' organisms.

The results of the biochemical tests of the chickens' blood allowed to make the conclusion that Sinbilite had the most intensive effect on the protein and carbohydrate metabolism. This way, the $3 \mathrm{~d}$ group, as compared with the other treatment groups, had its albumins higher by $14.9 \%$; $\alpha$-globulins by $23.3 \%$; and urea by $14.2 \%$.

Creatinine plays a major role in the energy metabolism of the muscle tissue. The increase of creatinine content signalizes the high intensity of muscle tissue growth [16]. Creatinine content in the blood of the subject chickens was above the regulatory data, The increase in creatinine in the 3rd group was $12.49 \%$, while in the 2 nd group, conversely, there was a non-credible decrease by $6.26 \%$.

Glucose is one of the important components of blood. Most of an organism's tissues depend on the immediate intake of glucose in the cells, particularly the following three types of cells: renal, muscle, and fat cells [17]. There were differences in glucose content in poultry blood observed between the groups. Thus, it was noted that including $\mathrm{NaBiKat}$ and Sinbilite in a bird's blood increased the glucose value in the 4 th group by $2.4 \%$ and by $11 \%$ in the 3 rd treatment group, though the changes may be non-credible. Sinbilite had the best effect on the carbohydrate metabolism in the 3rd group. This group's glucose level was higher than in groups 2 and 4 by $14.7 \%$ and $8.5 \%$ respectively.

Table 3 shows the parameters of the activity of the aminotransferases that reflect hepatocyte reaction.

TABLE III. EFFECT OF THE FEED ADDITIVES ON THE ACTIVITY OF THE AMINOTRANSFERASES OF BROILER CHICKEN BLOOD SERUM, (X+SX, N=5)

\begin{tabular}{|c|c|c|c|c|}
\hline \multirow{2}{*}{ Parameter } & \multicolumn{4}{|c|}{ Group } \\
\cline { 2 - 6 } & 1st control & 2nd treatment & 3rd treatment & 4th treatment \\
\hline AST, Mmol/1*h & $1.77 \pm 0.03$ & $1.90 \pm 0.06^{*}$ & $1.90 \pm 0.10$ & $1.63 \pm 0.09$ \\
\hline ALT, Mmol/1*h & $0.27 \pm 0.04$ & $0.28 \pm 0.04$ & $0.18 \pm 0.04$ & $0.18 \pm 0.06$ \\
\hline
\end{tabular}

The data from Table 3 display that the activity of blood transferases decreased in the statistically insignificant way in the groups where combined additives were fed. The AST content in all groups was below the normal data, but relative to the control the AST activity increased in the 2nd and 3rd groups by $7.3 \%$. The ALT activity in the group that used $\mathrm{NaBiKat}$ (group 2) was non-credibly higher by $3.7 \%$, while the $3 \mathrm{rd}$ and the 4 th treatment groups observed a decrease of ALT by $33 \%$ as compared to the control. More stable AST and ALT values were observed in the 2nd treatment group that was fed $\mathrm{NaBiKat}$ and in the 4th group that was fed a combination of $\mathrm{NaBiKat}$ and Sinbilite.

The results of micro- and macroelement study are presented in Table 4.

It has been established that the chickens from the 2nd and the 3rd treatment groups are marked with insignificant differences in blood calcium, magnesium, and iron, all within the norm. The 4th treatment group observed a credible $(\mathrm{P}<0.01)$ increase in calcium of $1.5 \%$ and, besides that, this same group was marked by the increase in iron of $35.9 \%$.

In group 2, where NaBiKat was introduced, there was a trend towards the decrease of phosphorus, manganese, copper and zinc, cobalt and lead by $3.3 \% ; 12.5 \% ; 3.4 \%, 11 \% 100 \%$ and $85 \%$ respectively. Cadmium was absent in all samples.

The goal of our studies included determining the most pronounced changes in the biochemical indicators of the blood serum that could forecast the productivity of broiler chicks. The study was based upon unidirectional changes. One of these indicators was total protein, because its increase was noted in all treatment groups. 
TABLE IV. EFFECT OF THE FEED ADDITIVES ON THE MICRO- AND MACROELEMENT COMPOSITION OF BROILER CHICKEN BLOOD SERUM, $(\mathrm{X}+\mathrm{SX}, \mathrm{N}=5)$

\begin{tabular}{|c|c|c|c|c|}
\hline \multirow{2}{*}{ Parameter } & \multicolumn{4}{|c|}{ Group } \\
\cline { 2 - 5 } & 1st control & 2nd treatment & 3rd treatment & 4th treatment \\
\hline Calcium Mmol/1 & $2.63 \pm 0.07$ & $2.69 \pm 0.11$ & $2.71 \pm 0.14$ & $3.04 \pm 0.09^{* *}$ \\
\hline Phosphorus Mmol/1 & $2.72 \pm 0.14$ & $2.63 \pm 0.12$ & $2.80 \pm 0.18$ & $2.76 \pm 0.03$ \\
\hline Magnesium Mmol/1 & $0.93 \pm 0.01$ & $0.99 \pm 0.04$ & $1.06 \pm ., 07$ & $0.99 \pm 0.09$ \\
\hline Manganese mg/1 & $0.08 \pm 0.01$ & $0.07 \pm 0.00$ & $0.0 \pm 0.01$ & $0.08 \pm 0.01$ \\
\hline Copper mg/l & $0.29 \pm 0.01$ & $0.28 \pm 0.00$ & $0.30 \pm 0.01$ & $0.26 \pm 0.01 *$ \\
\hline Zinc mg/l & $3.41 \pm 0.17$ & $3.03 \pm 0.02 *$ & $3.20 \pm 0.18$ & $3.32 \pm 0.16$ \\
\hline Iron mg/l & $143.70 \pm 10.42$ & $149.50 \pm 11.25$ & $144.70 \pm 14.18$ & $195.43 \pm 32.56$ \\
\hline Cobalt mg/l & $0.004 \pm 0.00$ & - & $0.002 \pm 0.00$ & $0.003 \pm 0.00$ \\
\hline Cadmium mg/l & - & - & - & - \\
\hline Lead mg/l & $0.07 \pm 0.004$ & $0.01 \pm 0.001$ & - & - \\
\hline Nickel mg/l & $0.01 \pm 0.00$ & $0.007 \pm 0.00$ & - & - \\
\hline \multicolumn{5}{|c|}{ d. Note: * when $\mathrm{P}<0.05 ; * *$ when $\mathrm{P}<0.01$}
\end{tabular}

It has been established that the chickens from the 2 nd and the 3rd treatment groups are marked with insignificant differences in blood calcium, magnesium, and iron, all within the norm. The 4th treatment group observed a credible $(\mathrm{P}<0.01)$ increase in calcium of $1.5 \%$ and, besides that, this same group was marked by the increase in iron of $35.9 \%$.

In group 2, where $\mathrm{NaBiKat}$ was introduced, there was a trend towards the decrease of phosphorus, manganese, copper and zinc, cobalt and lead by $3.3 \% ; 12.5 \% ; 3.4 \%, 11 \% 100 \%$ and $85 \%$ respectively. Cadmium was absent in all samples.

The goal of our studies included determining the most pronounced changes in the biochemical indicators of the blood serum that could forecast the productivity of broiler chicks. The study was based upon unidirectional changes. One of these indicators was total protein, because its increase was noted in all treatment groups.

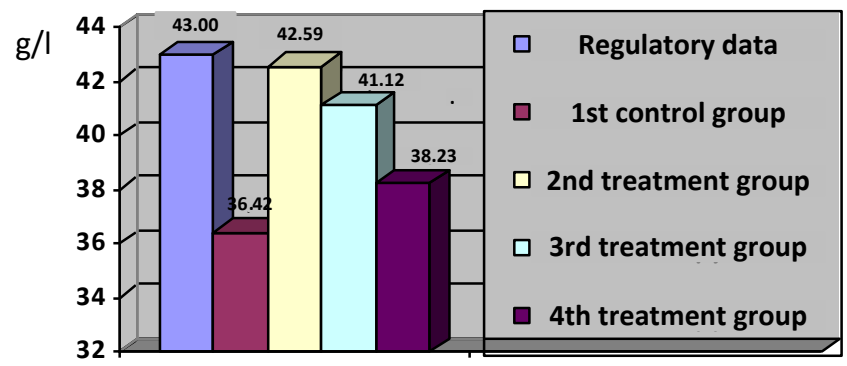

Fig. 1. Total protein content in broiler chickens (g/l)

The total protein content is presented in Figure 1, which displays that using feed additives increases protein content as compared with the control group, even 2 times in a number of cases.

The increase in creatinine concentration indicates the intensive development of muscles. Creatinine content above normal data (Fig. 2) can be considered a positive effect in terms of stimulating meat production.

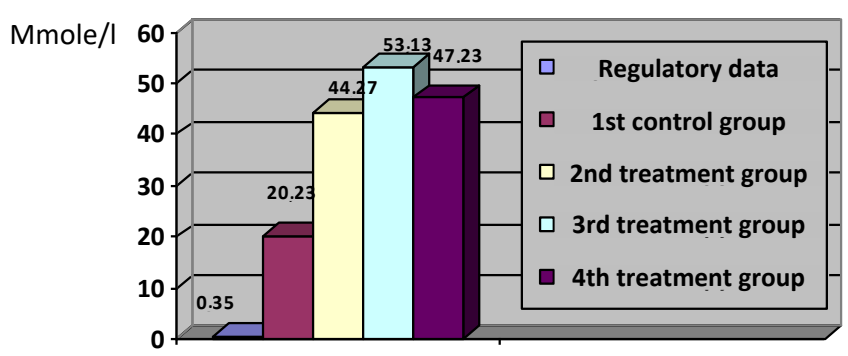

Fig. 2. Creatinine concentration in the blood of broiler chickens (Mmol/1)

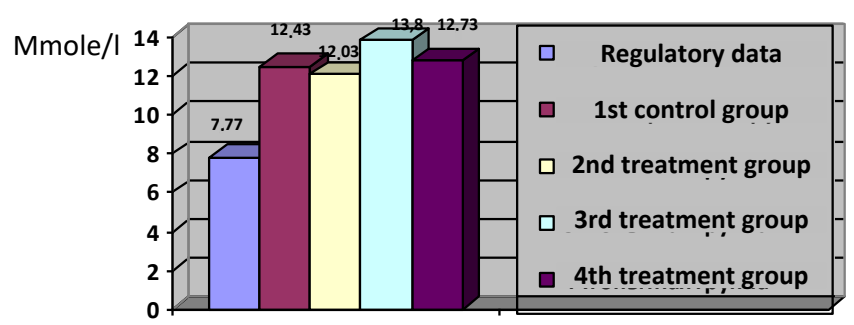

Fig. 3. Glucose content in broiler chick blood

The intensive growth and development of broiler chicks are facilitated by the forced decomposition of the glycogen reserves into glucose to provide an organism with energy reserves. This is displayed by the two-times increase of blood glucose above the normal standards (see Fig. 3).

An excellent style manual for science writers is [7].

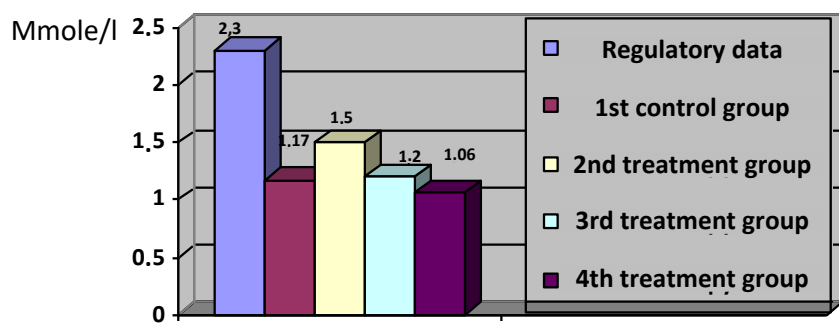

Fig. 4. Urea concentration in the blood of broiler chickens (Mmol/1) 
The lack of urea in the blood (Fig. 4) indicates the more pronounced use of protein under the high speed of muscle build-up.

\section{CONCLUSION}

Feed additives had a positive effect on the morphological and biochemical parameters of broiler chickens. NaBiKat facilitated the increase of the amount of red blood cells and hemoglobin, as well as the increase of the iron content. In its turn, Sinbilite stimulated the metabolism of proteins, carbohydrates, and minerals. It has been identified that the combined use of $\mathrm{NaBiKat}$ and Sinbilite is not feasible because a marked increase in productivity has not been achieved, while the production cost of the final product kept increasing. We consider that the markers of higher productivity of broiler chickens while using feed additives are the simultaneous decrease of the synthesis of urea, the increase of the total protein level, and the increase of the concentration of blood creatinine and glucose.

\section{References}

[1] V.A. Gudin, V.F. Lysov, V.I. Maksimov, "Physilogy and ethology of poultry birds" [Fiziologiia i etologiia selskokhoziaistvennykh ptitc]. St. Petersburg: Izdatelstvo Lan, 2010, p. 336.

[2] E. Timofeeva, "Microelements in feeding laying hens", [Mikroelementy v kormlenii kur-nesushek], Poultry Farming, 2012, No. 1, pp. 25-31.

[3] Sinbilite Pets, retrieved from: http://tdcvt.ru

[4] R. Temiraev, V. Ganiueva, N. Gachkoeva, "Probiotics and fermented compounds in chick rations" [Probiotiki i fermentnye preparaty $\mathrm{V}$ ratcionakh tcypliat], Poultry farming, 2009, No.4, pp. 20-21.

[5] N.Iu. Lazareva, "Microelements in broiler rations" [Mikroelementy v ratcionakh broilerov] Animal farming of Russia, 2012, No. 1, pp. 13.
[6] Nanobiologicheskii katalizator «NaBiKat», retrieved from http://nabikat.com

[7] A.S. Mizhevikina, I.A.Lykasova, D.V. Poluboiarov, V.B. Odeianko, "Broiler producivity when rationing with a complex of chelated microelements beneficial microorganisms, and chondroprotective agents", [Produktivnost broilerov pri ispolzovanii v ratcione kompleksa khelatirovannykh mikroelementov, poleznykh mikroorganizmov khondroprotektorov], Poultry and poultry products, 2017, No.1, pp. 40 42.

[8] A.S. Mizhevikina, I.A.Lykasova, D.V. Poluboiarov, "Study of changes in the intestine of broiler chickens when using NaBiKat and Sinbilite" [Issledovaniia izmerenii $\mathrm{v}$ kishechnike tcypliat-broilerov pri primenenii Nabikata i Sinbilaita], Poultry and poultry products, 2017, No.4, pp. 5659.

[9] Methods of veterinary clinical laboratory diagnostics: a textbook, I.P. Kondrakhina, ed. Moscow: KolosS, 2004, p.520.

[10] B.F. Bessarabov, S.A. Alekseeva, L.V. Kletikova, Laboratory of the Clinical and Immunobiological status of household poultry. Moscow: KolosS, 2008, p. 151

[11] V.S. Kamyshnikov, A reference book of clinical and biochemical laboratory diagnostics.Minsk: Belarus, 2002, p. 495.

[12] V.V. Kotomtcev, Clinical and biochemical parameters of animal blood [Kliniko - biokhimicheskie pokazateli krovi zhivotnykh]. Ekaterinburg: Medical bulletin, 2006, p.102

[13] Clinical biochemistry: a textbook, V.A. Tkachuk, ed Moscow: GeotarMedia, 2008, p. 264

[14] GOST 30178-96, Food products and raw materials. Atomic absorption spectroscopy of toxic elements. Introduced 1998.01.01. Moscow: IPK Izdatelstvo standartov, 1997, p.12.

[15] N. Buiankin, "Silica-organic additive for chicks" [Kremniiorganicheskaia dobavka dlia tcypliat], Russia's Animal Farming, 2011, No. 6, pp. 21-22.

[16] M. Ahmadi; A. Ahmadian; A. R. Seidavi, "Effect of Different Levels of Nano-selenium on Performance, Blood Parameters, Immunity and Carcass Characteristics of Broiler Chickens", Poultry science journal, 2018, vol. 6(1), pp. 99-108.

[17] S. M. H. Gilani; S. Zehra; Faiz-ul-Hassan; S. Galani; A. Ashraf, "Effect of natural growth promoters on immunity, and biochemical and haematological parameters of broiler chickens", Tropical journal of pharmaceutical research, 2018, vol. 17 (4), pp. 627-633. 